\title{
Modelling the fishing costs of French commercial vessels in the Bay of Biscay
}

\author{
Fabienne Daurès ${ }^{a, *}$, Verena M. Trenkel ${ }^{b}$, Olivier Guyader ${ }^{a}$
}

\author{
a Ifremer, UMR AMURE, Unité EM, Technopole de Brest-Iroise, BP 70, 29280 Plouzané, France \\ ${ }^{b}$ Ifremer, rue de l'île d'Yeu, BP 21105, 44311 Nantes cedex 3, France \\ *: Corresponding author : Fabienne Daurès, tel.: +33 298224924 ; email address : fabienne.daures@ifremer.fr
}

\begin{abstract}
:
Ten years after the start of the European Data Collection Framework the availability of cost indicators for assessing the economic status of fisheries or bio-economic modelling is still deficient. Moreover, economic time series are difficult to maintain due to fishermen weariness and sample coverage is often insufficient. To overcome these problems, the paper builds predictive models per operational cost category (fuel, landing, other variable, fixed, salary and total) for the French Bay of Biscay fleet. The cost models had good fit and stressed the key role of gear and vessel size (length mostly) for explaining fishing costs. They suggested that only a small list of variables was needed to predict costs (days-at-sea, total revenue, vessel age, length and power, district and fishing zone). These variables are easy to obtain for all vessels. In addition, some fitted cost models (total, landing and fixed costs) could be applied to the neighbouring English Channel, which suggested similarities between their fishing cost structures. Finally, the comparison of design-based and model-based cost estimates for the Bay of Biscay French fleet confirmed that modelling fishing costs on the basis of a small set of explanatory variables is a good alternative to design-based estimates which generally require costly annual sampling programs.
\end{abstract}

Keywords: Socio-economic ; Empirical cost model ; Fisheries performance ; Gear type ; GAM ; Ecosystem Approach to Fisheries

\section{Highlights}

- GAMs were built for variable and fixed fishing cost categories and gross-added value Explanatory variables were days-at-sea, total revenue, fuel price, gear, vessel power or length Some models fitted to the Bay of Biscay also performed well for the English Channel $>$ Precise model-based cost estimates provide input for bio-economic analyses $>$ Data sampling programs can be optimised.

\section{Introduction}

Since the publication of the FAO Code of conduct in 1995, consensus exists on ensuring long term sustainability of fisheries. More recently and particularly in the context of the EC reform of the common fishery policy (CFP), this objective is reaffirmed, considering ecological sustainability as well as economic and social ones. The collection of data for producing relevant economic fisheries indicators has been a big challenge for many countries for many years. These economic indicators are necessary for the assessment of the economic performance of fleets and fisheries (Ceriola et al., 2008, Anderson and Guillen, 2009, Brinson et al., 2009 and Gasalla et al., 2010), for bioeconomic analyses and impact assessments of 
management measures (Salz et al., 2010; Simmonds et al., 2011; Prellezo et al., 2012) or analyses of optimal size and structure of fishing fleets ( Bjorndal and Gordon, 2001; Pascoe, 2007). The data needs have recently considerably increased with the implementation of the Ecosystem Approach to Fisheries (EAF) (Garcia and Cochrane, 1995; FAO, 2005; Hilborn, 2011) for which the entire fishery system is to be considered in order to capture all the users' response to changes in resource dynamics (Salas and Gaertner, 2004).

Since 2001 under the EU Data Collection Framework (DCF), it is compulsory for EU member states to collect yearly cost and earnings data for commercial fishing vessels at national level. Cost data are collected through accounting data or face-to-face surveys (Le Floc'h et al., 2008; Le Corre et al., 2010). But increasingly, fishing firms are reluctant to provide economic information which they consider closely linked to their individual fishing strategy. Finally, information on fishing costs in most countries and regions of the world is still scarce, widely scattered and incomplete (Lam et al., 2011). For instance, the European Annual Economic report (Anderson and Guillen, 2009) focuses only on the important fleets at the European level, neglecting a large part of the coastal fisheries (Guyader et al., 2007). Even the DCF economic programme is now considered insufficient to support fishery management (Simmonds et al., 2011) because the available aggregated economic indicators do not reflect the situation of certain fisheries (see Commission Decision 2010/93/EU, appendix III).

The challenge of insufficient cost data was recently faced by Rochet et al. (2012) when trying to develop a model coupling ecological, biological and economic components for French fisheries in the Bay of Biscay. Given the large number of commercial fishing fleets competing in the Bay of Biscay and their heterogeneity in terms of technical features and catch strategies (Daurès et al., 2009), the non-availability of economic time series data at the required regional 
and fleet scales hindered taking into account all vessels. To overcome the lack of cost data, a range of predictive models of operational costs are presented here.

To model fishing costs they need to be differentiated by type (or category) and subcategory (Davidse et al., 1993; Whitmarsh et al., 2000). It is common to distinguish between variable (or running) costs, fixed (or vessel) costs, crew payments and capital costs. The first two are operational costs and refer to a short term consideration of economic performance while capital costs, including depreciation and opportunity costs, are important for a long term perspective of fisheries performance (Le Floc'h et al., 2008). Variable costs are costs varying with fishing effort and commonly include costs linked to items consumed during the fishing trip (fuel, ice, bait, food) plus landing costs (Brinson et al., 2009). Fixed costs are supposed to be constant whatever the level of the fishing effort and mainly concern repairs and maintenance costs and insurance premiums. Crew payments or salary costs include wages and social payments (social security costs).

In France, a cost and earnings data collection program was started in 2001 at national level and since then very detailed economic variables (related to the previous year) are collected annually through a questionnaire (Daurès et al., 2008). Based on a data set of annual vessel costs for French vessels fishing primarily in the Bay of Biscay from 2000 to 2009, the first part of this study aimed to find the best model for four cost categories (fuel cost, other variable costs, total fixed costs and salary costs) using as explanatory variables basic vessel information which is easily and broadly available. We started with a set of a priori explanatory variables derived from the literature for fishing effort, fishing methods and/or vessel features. This part of the study was not intended to estimate short or long-run cost functions (sensu Pascoe, 2007) but rather to investigate how much the fishing strategy 
described by the gears used and the vessel technical features (length, fishing power, crew size, age of vessel) influenced fishing costs, and which cost category the variables could actually explain. In addition to the cost category models, two additional models were built in a similar manner, one for gross added value and one for total costs.

The second part of the study dealt with the generality of fishing cost structures by comparing the Bay of Biscay and the neighbouring English Channel. The question addressed is which of the models parameterised for the Bay of Biscay also performs well for the English Channel, which would make some fisheries economic analyses applicable for the entire French Atlantic shelf fishery.

In the final part of the study the precision of model-based cost estimates for the Bay of Biscay fleet was compared to that of design-based cost estimates. If there is good correspondence between the two estimations this might indicate ways to optimise the annual cost data collection under the DCF.

\section{Material and Methods}

\subsection{Data}

Economic sampling data from French vessels operating primarily in the Bay of Biscay for the period 2000 to 2009 were used. These data were collected in face to face questionnaire interviews of a selection of vessel owners, stratified by harbours and vessel characteristics (size, gears). The vessel sampling strategy is proportional random with some vessels being 
kept in the sample for several years to increase the response rate, see full description in Van Iseghem et al. (2011). The economic sample data covered the range of vessel sizes about proportionally in all years except for larger vessels, which are generally bottom trawlers, which were underrepresented (Figure 1).

The annual data collected with the economic questionnaires were: number of seamen on board (crew) in addition to detailed information about the crew and the vessel sharing system, number of days at sea (days-at-sea), gross value of landings (total revenue) and detailed operational costs. These last items include costs for fuel (fuel costs) but also fuel volume (fuelvol; from 2002), costs for landings (landing costs), motor oil, bait, ice and subsistence of seamen, but also costs for maintenance and repairs of fishing equipment, gears and vessel parts, insurance premiums and administration $\operatorname{costs}^{1}$. Financial costs were not included in the analysis.

A number of derived cost variables were created. Total (or vessel) fixed costs (total fixed costs) are the sum of repairs and maintenance, insurance premium and administration costs. Other variable costs (other variable costs) are the sum of expenses for motor oil, bait, ice, subsistence of seamen etc. Total variable costs are the sum of fuel, landing costs and other variable costs. Total costs (total costs) are defined here as the sum of total variable costs and total fixed costs, thus excluding crew payments (salary costs). Crew payments (salary costs) are based mostly on the sharing system and include all the crew on board including the skipper-owner, who is also paid according to the amount of capital invested. For this study only vessels that went fishing were considered. Finally, gross added value (gross added value) is total revenue minus total costs. An average annual fuel price per litre (fuel price)

\footnotetext{
${ }^{1}$ The questionnaire is available in French at http://sih.ifremer.fr/Acquisition-des-donnees/Enquetes-economiques
} 
was derived as the mean of the ratio fuel costs to fuelvol; this is only available from 2002 as fuelvol was not recorded before.

In addition to these economic variables, information on vessel characteristics such as vessel length, engine power and age as well as the home harbour and maritime registration district (district) were available for all vessels (census data) and not only for those that filled in the economic questionnaire. Maritime registration districts were grouped into northern Brittany, southern Brittany, and central and southern Bay of Biscay. Further, certain information was collected for all vessels on a monthly basis: fishing zone, gears used, number of days at sea (days-at-sea) and number of days fishing (Berthou et al., 2008). Fishing zone has two levels here: coastal (within $12 \mathrm{~nm}$ of coast) and coastal \& offshore (within and beyond $12 \mathrm{~nm}$ ).

For this study 2507 vessels operating in the Bay of Biscay were grouped into 11 fleets based on the gear combination used in the surveyed year ${ }^{2}:$ 1) bottom trawl, 2) pelagic trawl, 3) mixed trawls which combined bottom and pelagic trawls, 4) other trawls which combined trawls and dredges, 5) dredge which could be exclusive or polyvalent (except trawls), 6) other active gear which are mostly sieves, 7) hooks, 8) nets, 9) pots, 10) seine and 11) other passive gear. Sample size varied across gear categories (gear) where one sample corresponded to information from one vessel for one year (Table 1). In the case of the use of different gears, for example the mixed trawl category, both bottom and pelagic trawls were used during the year, but not necessarily during the same trip or month.

\footnotetext{
${ }^{2}$ To clarify the terminology, the gear is the tool used by the fishermen to catch the species. Based on the gear(s) they used during the year, vessels are assigned to a fleet segment and a gear category. The gear category is the terminology used for the sample while the fleet segment represents all the vessels in the same gear category during a given year.
} 


\subsection{Economic modelling}

Generalised additive models (GAM) were formulated for seven economic variables: fuel costs, landing costs, salary costs, other variable costs, total fixed costs, total costs and gross added value (Table 2). The modelling was carried out on an annual level as many economic variables were only available annually. Spline functions were used for continuous explanatory variables. Separate functions for each gear category were also tested. In this case a common (main effects) relationship plus one per gear category was fitted. For each economic variable the full model was formulated based on a priori hypotheses on influential vessel and fishing activity variables derived from expert knowledge. It systematically included year as explanatory variable.

Fuel costs have the reputation to be a major operational cost of fishing vessels, especially for large vessels using active gears like trawls (Planchot and Daurès, 2008; Abernethy et al., 2010). Thus it is not surprising that fuel costs have been found to be influenced by gear type and vessel length (Tyedmers, 2001; Abernethy et al., 2010; Le Floc'h et al., 2012). Fuel consumption and costs are also expected to vary with the fuel price, given that the increasing trend of fuel prices worldwide during the last fifteen years has strongly affected fisheries performances (Salz, 2006).

Landing costs are variable costs mainly consisting of the fees paid by the vessel when the catches are landed. Rather than fishing effort, these costs are expected to be mostly influenced by the total revenue (volume of landings * ex-vessel prices) but the role of the size of the vessel and the harbour where the fish are landed were also investigated. In most cases, the landing harbour corresponds to the harbour where the vessel is registered. 
Fuel and landing costs are the major items of the so called variable or running costs. Other variable costs are various expenses during a fishing trip. It is expected that these costs depend on fishing effort, the size of the vessel and the distance to the coast. Given that the sharing system still occurs in the fishing sector, salary costs are expected to be mostly impacted by the level of total revenue registered by the vessel. The full model for salary costs included fishing effort, vessel size and registered harbour.

Total fixed costs are expected to be strongly influenced by the size of the vessel and its age, through the repairs and maintenance expenses (Le Floc'h et al., 2011). Given the geographic spread of the Bay of Biscay fleet, the role of the registered harbour on the total fixed costs is also tested. The formulation of the full models for total costs and gross added value were basically the same, including vessel size, gear and fishing activity. In addition, the age and total revenue were also considered for modelling total costs.

In each case the final model was selected based on the lowest Bayesian Information Criterion (BIC). Model goodness-of-fit was measured by the percentage explained deviance. As all economic variables were positive and had skewed distributions, Gamma distributions with log-link functions were used in all cases. Models were fitted using the mgcv package (Wood 2006) in $\mathrm{R}$ ( $\mathrm{R}$ Development Core Team 2012) with parameter estimation by residual maximum likelihood (REML). Residual plots were utilized to check model assumptions. In particular, it was checked that the residuals for the final models were not biased for any of the 11 gear categories. 
Due to missing information for relevant covariables or the economic variable, the sample size in each model varied (Table 2). For example, for modelling landing costs, only data for the 2265 vessels (90\%) having landed their catch in a fish auction and thus having had to pay these costs was included in the modelling. The vessels selling their catch directly and entirely outside the fish auction system were primarily small vessels $(<12 \mathrm{~m})$ using pots and other passive gears. Information on salaries was only available from 2001 onwards.

\subsection{Generality of the models}

The generality of the fitted models was evaluated by using them to predict costs and gross added value for French vessels operating in the English Channel for which the same information was collected for the period 2000 to 2009. Overall 1508 samples were available for this test. Predicted and observed economic variables were compared for both the Bay of Biscay and the English Channel vessels using a Taylor diagram (Taylor, 2001). In a Taylor diagram the ratio of standard deviations $\left(\sigma_{\text {pred }} / \sigma_{\text {obs }}\right)$, the root mean square errors (RMSE) and the Spearman correlations for each comparison are plotted together. Values were standardised so that the observations in the Bay of Biscay had correlation 1 with themselves, standard deviation 1 and RMSE 0. The Taylor diagram was created using the plotrix package in $\mathrm{R}(\mathrm{R}$ Development Core Team 2012).

Some of the fitted final models included the district explanatory variable which is specific to the Bay of Biscay. Therefore, when predicting for the English Channel vessels, the district variable was set to the level with zero effect (central Bay of Biscay). 


\subsection{Cost estimation at the fleet segment level}

There are two ways for raising fishing related costs from the sample to the fleet segment level: design-based estimation (Cochran, 1953) or model-based estimation. Traditionally design-based estimators are used for raising economic information in fisheries (Anderson and Guillen, 2009; Leblond et al., 2011). Using the models developed here, model-based estimation is also possible given all covariables exist for all vessels.

Design-based and model-based cost estimates raised to the fleet level for each gear category were compared in terms of the fleet level cost estimates and the achieved precision using the coefficient of variation (CV). Design-based estimation was achieved by using a stratified random estimator with the gear categories as post strata.

\section{Results}

\subsection{Exploratory analysis}

The average cost structure for the period 2000 to 2009 was quite different across gear categories, though salary costs represented the largest expenses for all categories amounting to at least $40 \%$ (Figure 2). For trawlers, fuel costs were another major cost. They represent more than $20 \%$ of total costs and explained the high level of total variable costs for this gear category. A high share of other variable costs was observed for pots and hooks, which was caused by bait expenses. Differences in the contribution of variable costs showed no clear 
separation between active and passive gears. The part of total fixed costs was high for nets $(30 \%)$ and lower for trawlers and the fleet of other passive gears $(20-25 \%)$.

The absolute value of annual fuel costs varied strongly within and between gears with a strong difference between trawlers (more than 200 Euros/day-at-sea) and all other gears (Figure 3a). The cost of fuel varied also between trawl categories, with the highest level for pelagic trawls (400 euros/day-at-sea on average). Part of the within gear variability was certainly explained by the variation of the fuel prices during the study period (Daurès et al., 2009). Landing costs increased with total revenue and depended to some degree on the maritime vessel registration region which was interpreted as a proxy for the harbour in which catches were landed (Figure 3b). Salary costs were linearly related to total revenue, possibly with a different slope for different gears (Figure 3c). Other variable costs followed the same pattern across gears as fuel costs with relative high levels and variability of expenses observed for pots and seines compared to other non trawlers (Figure $3 \mathrm{~d}$ ). The ratio of total costs (excluding salary) per total revenue distinguished trawlers clearly from other gear categories, the latter being much more cost efficient (Figure 3e). No clear relationship appeared between standardised fixed costs (euros per meter of vessel length) and the age of the vessel suggesting other explanatory factors (Figure 3f). A slight positive relationship was observed between daily productivity (measured through gross value added per day-at-sea) and vessel size (power), with higher variability of economic performance as power increased (Figure $3 \mathrm{~g}$ ).

The sample of vessels for which economic data were available was primarily made up of small vessels $(<12 \mathrm{~m})$, except for trawlers and seiners (Figure 4). Comparing the technical vessel characteristics between the sampled vessels and the fleet, no large differences occurred except for pelagic trawlers for which larger vessels were underrepresented in the sample. In 
terms of total revenue the sample and fleet showed similar distributions. In contrast, days-atsea for the fleet were lower and more variable than for the sample data, suggesting that the fleet data set were incomplete. The technical characteristics (length, horse power and crew size) depended largely on the gear being deployed: the largest vessels were found within the trawlers category but also seiners. All other fishing techniques, based on active or passive gears, were mostly used by small vessels $(<12 \mathrm{~m})$. Most vessels were around 20 years old and spent around 200 days at sea, independent of the gear used. Total revenue was also gear dependent.

\subsection{Economic models}

All final models selected by BIC explained a large part of the observed variability with the percent explained deviance ranging from $60.9 \%$ for other variable costs model to $97.8 \%$ for salary costs model (Table 2). No gear effects were found for residuals indicating that all models were equally good for all gear categories.

Fuel costs were explained by the product of fuel price and days-at-sea and vessel power according to the gear used. The year and the fishing zone did not significantly influence fuel costs. The final model explained more than $82 \%$ of the deviance. Landing costs were explained by the district, the level of total revenue and vessel length. No year influence was found; the final model had a somewhat low percentage explained deviance (73\%). Other variable costs were explained by the gear used, fishing zone, the days-at-sea and vessel length. Despite this large set of explanatory variables, the explained deviance of this best model was comparatively low (61\%). Salary costs were explained by year, days-at-sea and total revenue, with a specific model per gear for total revenue. The final model explained 
almost $98 \%$ of the deviance. Total fixed costs were explained by year, the gear used but also vessel length and age. The final model fitted rather well (80.8\% deviance explained).

The final model for total costs (excluding salaries) suggested a significant influence of technical vessel characteristics (length and age) in addition to the gear used and total revenue. Differences between years were found while fishing effort (days-at-sea or fishing zone) had no significant explanatory power for total costs considered as a whole. The final total costs model explained $92.4 \%$ of deviance. The model for gross added value suggested that the main factors were fishing effort (fishing zone and days-at-sea) in addition to technical vessel features (vessel length and power). No year and gear influences were found, but this final model only explained $65.8 \%$ of deviance.

In summary, significant inter annual variations were only found only for salary costs, total fixed costs and total costs. The year effect showed no time trend for total costs while it increased for total fixed costs. Salary costs decreased from 2001 to 2005 and increased thereafter (not shown).

Unsurprisingly, both vessel size and fishing gear strongly influenced fishing costs. Except for salary costs, the vessel size, measured through length or power, contributed to explaining all fishing cost categories. Length appeared to be the best proxy of vessel size for the majority of cost models, except for the fuel costs where the power was more important. This is certainly the reason why vessel length and power were both influencing gross added value. Vessel age was another explanatory variable, especially for total fixed costs. The gear variable was significant for all fishing costs except landing costs and contrary to expectation it did not influence gross added value. The gear influence was direct and global (main effect) for other 
variable costs, total fixed costs and total costs. It was indirect through differently shaped relationships for engine power in the model for fuel cost and for total revenue in the model for salary costs.

Parallel to the technical features of the vessel (size, age and gears used), the fishing activity can also be a strong explanatory variable of fishing costs. For instance, total revenue and/or days-at-sea were significant explanatory variable for salary costs and unsurprisingly, for all variable costs: fuel costs, landing costs and other variable costs. Hence, it is not surprising that gross added value and total costs were also explained by the fishing activity/effort.

Figures 5 and 6 show the main effect relationships for some of the continuous explanatory variables. These relationships are on the level of the linear predictor that is on the log-scale as a log-link function was used. Landings costs, salary costs and total costs showed a positive relationship with total revenue (Figure 5). The effect of vessel length on landings costs increased strongly up to about $9 \mathrm{~m}$ and then levelled off. In contrast, for total fixed costs, total costs and gross added value the effect of vessel length continued to increase throughout the range of vessel lengths. Days-at-sea were positively related to salary costs and gross added value. Total fixed costs decreased generally with vessel age, though there is slight increase for vessels aged 10 to 20 years. Interestingly, gross added value had a dome-shaped relationship with vessel power (Figure 6).

\subsection{Model validation and generality}

Comparison of observed and predicted economic variables using the final selected models confirmed the good model fits for the Bay of Biscay (lower case letters in Figure 7). The 
correlations between observations and model predictions were all between 0.8 (gross added value) and 0.96 (salary costs). With the exception of gross added value, the RMSE between model predictions and observations was less than 0.5. Standard deviations of model predictions were all smaller than observed variations, i.e. within the circle indicating a ratio of one.

The generality of the fitted economic models for the Bay of Biscay was evaluated by using them to predict costs for vessels operating in the English Channel. As shown by the Taylor diagram, the Bay of Biscay models performed well for the English Channel of predicting total costs, total fixed costs and landing costs (upper case letters in Figure 7). For these three variables the correlation between observed and predicted values was between 0.8 and 0.9 , the RMSE was less than 0.7 and the scaled standard deviation was between 0.5 and 1 . The predictions for fuel costs were completely wrong, with a correlation between observations and predictions of only 0.25 and a very high relative standard deviation (not shown). For gross added value, other variable costs and salary costs the models did not provide good predictions either (corelation coefficients around 0.5). In summary, the fitted Bay of Biscay models for total cost, total fixed costs and landing costs seem to be general enough also to describe the cost structure in the English Channel, while the Bay of Biscay models are unsuitable for the other economic variables. The results need to be interpreted with cautious for landing costs because of the district effect, set to zero for the English Channel application while significant for the Bay of Biscay model.

\subsection{Fleet predictions}


Fleet level estimates for total costs summed over all gear categories were a little bit higher for model-based estimates compared to design-based estimates (Figure 8a). These patterns were confirmed when comparing the sum of total fixed and total variable costs excluding salaries (Figure 8b). The model-based fleet level estimates for total costs obtained either by using directly the model for total costs or by summing the model-based estimates for cost components agreed rather well in contrast to the design-based estimates. Finally, the coefficient of variations of annual fleet level cost estimates were much higher for designbased estimates, around 0.2 (Figure 8c) compared to model-based estimates which had CVs closed to 0 (Figure 8d).

\section{Discussion}

Economic data collection is a continuous challenge for fisheries research and management since the beginning of $90 \mathrm{~s}$, when first attempts were made to compile cost and earnings data of fishing fleets at the European level (Davidse et al., 1993). This first initiative, focusing only on four European countries (France, Denmark, Netherlands and United Kingdom), was followed by a large concerted action funded by the European Commission which gathered research institutes from more than 20 countries and started to produce a yearly "Economic Assessment of European Fisheries" between 1998 to 2005. The inclusion of economic indicators in the scope of the compulsory data collection for EU member states $^{3}$ at the beginning of the 2000s was a major step for fisheries research and management because it contributed to make permanent the economic and biologic data collection through successive European data collection regulations (DCR from 2000 to 2008; DCF from 2009 onwards).

\footnotetext{
${ }^{3}$ COUNCIL REGULATION (EC) No 1543/2000 of 29 June 2000
} 
The stakes of economic data collection are obvious for fisheries management and particularly for impact assessments of management measures. At the beginning of the $2000 \mathrm{~s}$, cost and earnings fleet data started to be used in the advisory process at European level initially through the Economic Interpretation of ACFM Advice (or EIAA model) which tried to assess the impact of annual TACs for major European stocks on fleet economic performance (Frost et al., 2009). Recently, Prellezo et al. (2012) reviewed 13 bio-economic models used for the evaluation of EU policies. However, the data needs are still increasing and the recent implementation of the EAF has significantly extended these data needs. Unfortunately, the economic data collection program becomes more and more difficult to implement in national sampling programs (Van Iseghem et al., 2011) because it does not cover all vessels as a small number companies owning large vessels are reluctant to provide economic information and the program in general increasingly faces the unwillingness of fishermen to participate.

By analysing all economic data of the French data collection program, this study significantly increases the knowledge on cost structures in the fishing sector. Indeed, the final fuel costs model confirms the strong influence of the gear, vessel size, fuel price and the fishing effort (Tyedmers, 2001; Abernethy et al., 2010; Le Floc'h et al., 2012). The absence of a year effect for fuel costs may be the consequence of no change in fishing behaviour which would have reduced fuel consumption in contrast to the behaviour change observed for Dutch beam trawlers (Bear et al., 2012). Indeed, in the Bay of Biscay no major changes were observed in the annual number of days-at-sea. While other explanatory variables were sometimes also proposed to explain fuel costs, like skipper ownership (Abernethy et al., 2010) or past total revenue (Le Floc'h et al., 2012), the good fit of the fuel costs model suggests that no other factors seem important for the French Bay of Biscay vessels. 
The landing costs model demonstrated the key role of vessel length and district in addition to total revenue for the Bay of Biscay fleets. Additional variables to vessel sales would be necessary to better explain landing costs, which are generally considered a linear function of total revenue in bio-economic models (Prellezo et al., 2012). This study confirmed differences in vessel sales' behaviour according to vessel length. Remember that vessels not paying any landing costs were excluded from the modelling. As shown by Leblond et al. (2011), the part of the fish production of the French Atlantic fleets passing through the official auction hall network increases with vessel size ( $>90 \%$ for vessels $>12 \mathrm{~m} ; 70-80 \% 10-12 \mathrm{~m}$ and $30-40 \%<7 \mathrm{~m}$ ). Thus a large proportion of small size vessels sell their catches outside auctions and don't pay landing costs at least for a part of their landings. This behaviour difference between vessels of different size was also observed in the English Channel fleet and may be an explanation for the good predictions of the Bay of Biscay landing cost model of English Channel landing costs, despite the lack of information on the district parameter for this area.

The total fixed costs model confirmed the key role of vessel age for maintenance and repair expenses, in addition to gear used and vessel size (Le Floc'h et al., 2011). In addition, significant year differences were found, which suggests specific circumstances influenced total fixed costs in certain years only. This is consistent with the role of fiscal policies for maintenance and repairs expenses identified by Le Floch et al. (2011). Finally, the excellent model fit for salary costs is satisfactory given the first rank of this cost in the fishing cost structure. It confirms the key role of the total revenue for crew expenses, according to the share system, which is still the most usual crew payment system in France (Boncoeur et al., 2000), but not necessarily the only retribution system in fisheries across Europe. 
Vessel size and gear played a key role in explaining fishing costs. This is consistent with current bio-economic models which are often parameterised as cost per vessel group (size and gear groups) (Prellezo et al., 2012). It also confirms the methodology used for economic data collection under the DCF which is based on fleet segments and vessel size groups or more recently the methodology used for the construction of the global fishing cost database which is also based on gear types (Lam et al., 2011). However, the results also highlight the influence of additional variables for fishing costs, which vary between the different cost categories. Because the final models only include a small number of explanatory variables, these models could contribute to the formulation of bio-economic models, in particular for models which differentiate between variable and fixed costs within operational costs (Frost et al., 2009; Prellezo et al., 2012). Indeed, predictive costs models such as those developed here offer an interesting way to make bio-economic models independent of data availability. They could also be useful for the EAF approach where the structure of fisheries is generally complex. Given the good fit and the very high correlation between observed and predicted costs for all models, the final cost models will soon be applied to the Bay of Biscay, where a large diversity of vessels (1800 French commercial fishing vessels) are operating and together land almost 200 species (Daurès et al., 2009). Care must however been taken regarding the lack of large offshore (pelagic) trawlers in the sample which might mean that cost predictions on the fleet level might not be reliable for this fleet. Furthermore, the dome-shaped relationship between the Gross Added Value and the vessel power (kW) should not be interpreted as informing on optimal vessel capacity or size for several reasons. First, it is probably the consequence of the non-linear relationship between vessel power and length. Second, optimal size is generally assessed through the invested capital not vessel power. 
The application of the Bay of Biscay cost models to the English Channel were found to be possible for total costs and total fixed costs, but appeared problematic for salary and fuel costs. Structural differences between the two areas can explain this result. For fuel costs, possible reasons could be the distance of fishing grounds (closer for the English Channel) and the management system in place (fishing is allowed only for a certain number of hours per day for some English Channel fisheries). Hence, one day at sea in the English Channel implies different amounts of fuel used compared to the Bay of Biscay. Further, beam trawlers are present in the English Channel, but absent from the Bay of Biscay and so cost models could not be developed for them. Future studies are needed to further elucidate the differences between the two areas.

The application of the Bay of Biscay cost models to the English Channel revealed the difficulties that would occur if the models were used on to a larger spatial scale. These difficulties raise the question whether the explanatory variables and/or the values of the model coefficients should be the same or not on the European level. It can be expected that differences in fiscal policies and social regimes between countries will hamper the predicting of fishing costs across Europe using a single set of models. Nevertheless, several model fitting comparisons for different areas could carried out and may be used to define a set of cost models useable at the European level, even though the models might turn out not be satisfactory for any given area.

Faced with the difficulty to update annually the fishing cost data base, which generally requires voluntary involvement of fishing enterprises, our predictive cost models offer an interesting alternative for fisheries analyses, ranging from the assessment of the economic status of fisheries to bioeconomic modelling, provided data for explanatory variables exist for 
the whole fleet. The comparison of the precision and accuracy of model-based cost estimates with design-based estimates was largely in favour of model based estimates. CVs were much lower for model-based estimates and the sum of separate cost estimates was closer to direct total cost estimates, which can be interpreted as higher accuracy. The cost models could also be used to redesign and optimize the sampling plan, in particular to ensure year effects were estimable reliably. Only a subset of variables available for all vessels would then be enough to predict annual costs in more or less details. For instance, only total revenue, gears, vessel age and length would be necessary for estimating the basic economic situation (operational profit by total and salary cost estimates) per fleet and fleet segment. Although the best salary cost model requires many variables, probably not all are necessary if some reduction in model performance is accepted. It would be interesting to compare across areas what minimum set of explanatory variables are needed and to what level of bias this might lead. Finally, this study showed that in the Bay of Biscay, total revenue itself explains the major part of the deviance of the salary costs and could be enough for their prediction.

How could our modelling help to improve the annual economic data collection across Europe? The European fishing fleet register contains the technical characteristics of commercial fishing vessel registered in member states (length, power, age) plus information on registered harbour (district). The data collection strategy could then be directed to ensure the quality of individual data on fishing activity (gears used and fishing zones) and to complement urgently the European official fisheries statistics with this information. This is necessary because the gears registered in the European Fishing fleet register seem not to be regularly updated (Guyader et al., 2007). To achieve this, the coverage of log-books and sales notes from which total revenue and gears used can be derived must be complete, if not it could be supplemented with surveys and/or additional sources (Berthou et al., 2008). 
Information on fishing methods must be detailed enough; a simple distinction between active and passive is insufficient.

\section{Acknowledgements}

This study received financial support from the EU FP7 grant FACTS (Forage Fish Interactions), grant agreement no. 244966. All the data are made available through the IFREMER SIH “Système d'Informations Halieutiques" (Fleet and Activity data, Economic data) and we would like to thank the SIH team and the Ministry of fisheries for providing them. We also thank two anonymous referees for their useful comments. The economic data used for this study were partly funded by the European Union under the Data Collection Framework (DCF).

\section{References}

Abernethy, K.E., Trebilcock, P., Kebede, B., Allison, E.H., Dulvy, N.K., 2010. Fuelling the decline in UK fishing communities? ICES Journal of Marine Science 67, 1076-1085.

Anderson, J., Guillen, J., 2009. The Annual Economic Report on the European Fishing Fleet Scientific, Technical and Economic Committee for fisheries (STECF). JRC Scientific and Technical Reports - Report EUR 24069 EN, 311p.

Bear, D., Machiels, M., 2012. Beam trawlermen take feet off gas in response to oil price hikes. ICES Journal of Marine Science 69, 1064-1068 
Berthou, P., Guyader, O., Leblond, E., Demanèche, S., Daurès, F., Merrien, C., Lespagnol, P., 2008. From fleet census to sampling schemes: an original collection of data on fishing activity for the assessment of the French fisheries. ICES CM 2008/ K: 12, Halifax.

Bjorndal, T., Gordon, D.V., 2001. The economic structure of harvesting for three Vessel types in the Norwegian Spring-Spawning Herring Fisheries. Marine Resource Economics 15, 281292.

Boncoeur, J., Coglan, L., Le Gallic, B., Pascoe, S., 2000. On the (ir)relevance of rates of return measures of economic performance to small boats. Fisheries Research 49, 105-115.

Brinson, A., Die, D., Bannerman, P., Diatta, Y., 2009. Socioeconomic performance of West African fleets that target Atlantic billfish. Fisheries Research 99, 55-63.

Ceriola, L., Accadia, P., Mannini, P., Massa, F., Milone, N., Ungaro, N., 2008. A bioeconomic indicators suite for the appraisal of the demersal trawl fishery in the Southern Adriatic Sea (Central Mediterranean). Fisheries Research 92, 255-267.

Cochran, W.G., 1953. Sampling techniques, John Wiley \& Sons, New York.

Daurès, F., Van Iseghem, S., Demanèche, S., Leblond, E., Brigaudeau, C., Guyader, O., Berthou, P., 2008. Re-assessing the French small-scale coastal fisheries: from fleet activity to economic performance. ICES CM 2008 / K:10, Halifax. 
Daurès, F., Rochet, M.-J., Van Iseghem, S., Trenkel, V.M., 2009. Fishing fleet typology, economic dependence, and species landing profiles of the French fleets in the Bay of Biscay, 2000-2006. Aquatic Living Resources 22, 535-547.

Davidse, W.P., 1993. Costs and earnings of fishing fleets in four EC countries. Agricultural Economics Research Institute (LEI-DLO), The Hague, p. 202 p.

FAO, 2005. Putting into practice the ecosystem approach to fisheries. Rome, FAO, 76p.

Frost, H., Andersen, J.L., Hoff, A., Thogersen, T., 2009. The EIAA Model: Methodology, Definitions and Model Outline. Institute of Food and Resource Economics, Copenhagen, p. $75 p$.

Garcia, S.M., Cochrane, K.L., 2005. Ecosystem approach to fisheries: a review of implementation guidelines. ICES Journal of Marine Science 62, 311-318.

Gasalla, M.A., Rodrigues, A.R., Duarte, L.F.A., Sumaila, U.R., 2010. A comparative multifleet analysis of socio-economic indicators for fishery management in SE Brazil. Progress in Oceanography 87, 304-319.

Guyader, O., Berthou, P., Koustikopoulos, C., Alban, F., Demaneche, S., Gaspar, M., Eschbaum, R., Fahy, E., Tully, O., Reynal, L., Albert, A., 2007. Small-scale coastal fisheries in Europe. EC Report, FISH/2005/10, 447 p, http://archimer.ifremer.fr/doc/2007/rapport6348.pdf 
Hilborn, R., 2011. Future directions in ecosystem based fisheries management: A personal perspective. Fisheries Research 108, 235-239.

Lam, V.W.Y., Sumaila, U.R., Dyck, A., Pauly, D., Watson, R., 2011. Construction and first applications of a global cost of fishing database. ICES Journal of Marine Science 68, 19962004.

Le Corre, L., Brigaudeau, C., Daurès, F., Le Floc'h, P., Van Iseghem, S., Guyader, O., 2010. Les indicateurs économiques à la pêche - Analyse comparative des données comptables et d'enquête. Ifremer SIH, Publications électroniques Amure, Série Observation et données OD05-2010, 53 pp. www.umr-amure.fr

Le Floc'h, P., Daures, F., Brigaudeau, C., Bihel, J., 2008. A comparison of economic performance in the fisheries sector: A short- and long-term perspective. Marine Policy 32, $421-431$

Le Floc'h, P., Daures, F., Nourry, M., Thebaud, O., Travers, M., Van Iseghem, S., 2011. The influence of fiscal regulations on investment in marine fisheries: A French case study. Fisheries Research 109, 257-264.

Le Floc'h, P., Daurès, F., Guyader, O., Wilson, J., 2012. A Case Study of Technological switching and Technological Lock-in in the French Fisheries Sector: Why is Sustainable Change so Difficult? Canadian Journal of Agricultural Economics 60, 541-559. 
Leblond, E., Daurès, F., Berthou, P., Merrien, C., Pitel, M., Macher, C., Le Grand, C., Demanèche, S., Jezequel, M., Bodéré, E., Le Blond, S., 2011. Synthèse des flottilles de pêche 2009 - Flotte Mer du Nord - Manche - Atlantique et Flotte Méditerranée. Ifremer, SIH Synthèses, 294 pp.

Pascoe, S., 2007. Estimation of cost functions in a data poor environment: the case of capacity estimation in fisheries. Applied Economics 39, 2643-2654.

Planchot, M., Daurès, F., 2008. Le secteur français des pêches maritimes face à l'augmentation $\quad \mathrm{du} \quad$ prix $\mathrm{du}$ gasoil. http://sih.ifremer.fr/Contenussih/Publications/Syntheses/Notes-de-synthese, 19 pp.

Prellezo, R., Accadia, P., Andersen, J.L., Andersen, B.S., Buisman, E., Little, A., Nielsen, J.R., Poos, J.J., Powell, J., Rockmann, C., 2012. A review of EU bio-economic models for fisheries: The value of a diversity of models. Marine Policy 36, 423-431.

R Development Core Team, 2012. R: A language and environment for statistical computing. R Foundation for Statistical Computing, Vienna, Austria. ISBN 3-900051-07-0, URL http://www.R-project.org/.

Rochet, M.-J., Daurès, F., Trenkel, V.M., 2012. Capacity management, not stock status or economics, drives fleet dynamics in the Bay of Biscay ecosystem on a decadal time scale. Canadian Journal of Fisheries and Aquatic Sciences 69, 695-710. 
Salas, S., Gaertner, D., 2004. The behavioural dynamics of fishers: management implications. Fish and Fisheries 5, 153-167.

Salz, P., 2006. Economic performance of EU fishing fleets and consequences of fuel price increase. in European Commission Directorate General for Fisheries and Maritime Affairs (Eds), Conference on Energy efficiency in fisheries. Brussels, May, pp. 6-13.

Salz, P., Buisman, E., Soma, K., Frost, H., Accadia, P., Prellezo, R., 2010. Study on the remuneration of spawning stock biomass. Final report - Framian, 298 pp. http://ec.europa.eu/fisheries/documentation/studies/remuneration_of_the_spawning_stock_bio mass_en.pdf

Simmonds, E.J., Doering, R., Daniel, P., Angot, V., 2011. The role of fisheries data in the development evaluation and impact assessment in support of European fisheries plans. Ices Journal of Marine Science 68, 1689-1698.

Taylor, K.E., 2001. Summarizing multiple aspects of model performance in a single diagram. Journal of Geophysical Research 106, 7183-7192.

Tyedmers, P., 2001. Energy consumed by North Atlantic Fisheries. In: Zeller, D., Watson, R., Pauly, D.s (Eds.), Fisheries' Impacts on North Atlantic Ecosystems: Catch, Effort and National/Regional Datasets. Fisheries Centre, University of British Columbia, Vancouver, pp. $12-34$. 
Van Iseghem, S., Quillerou, E., Brigaudeau, C., Macher, C., Guyader, O., Daures, F., 2011. Ensuring representative economic data: survey data-collection methods in France for implementing the Common Fisheries Policy. ICES Journal of Marine Science 68, 1792-1799.

Whitmarsh, D., James, C., Pickering, H., Neiland, A., 2000. The profitability of marine commercial fisheries: a review of economic information needs with particular reference to the UK. Marine Policy 24, 257-263.

Wood, S.N., 2006. Generalized additive models. An introduction with R. Chapman \& Hall/CRC, Boca Raton. 
Table 1. Total sample size by fishing gear and area for the economic survey of French vessels operating in the Bay of Biscay (2000-2009). Mixed trawl: pelagic and bottom; other trawl: trawls combined with dredges, sieves or passive gear; other active: sieves or sieves and other passive gears; other passive: combination of hooks, pots and nets.

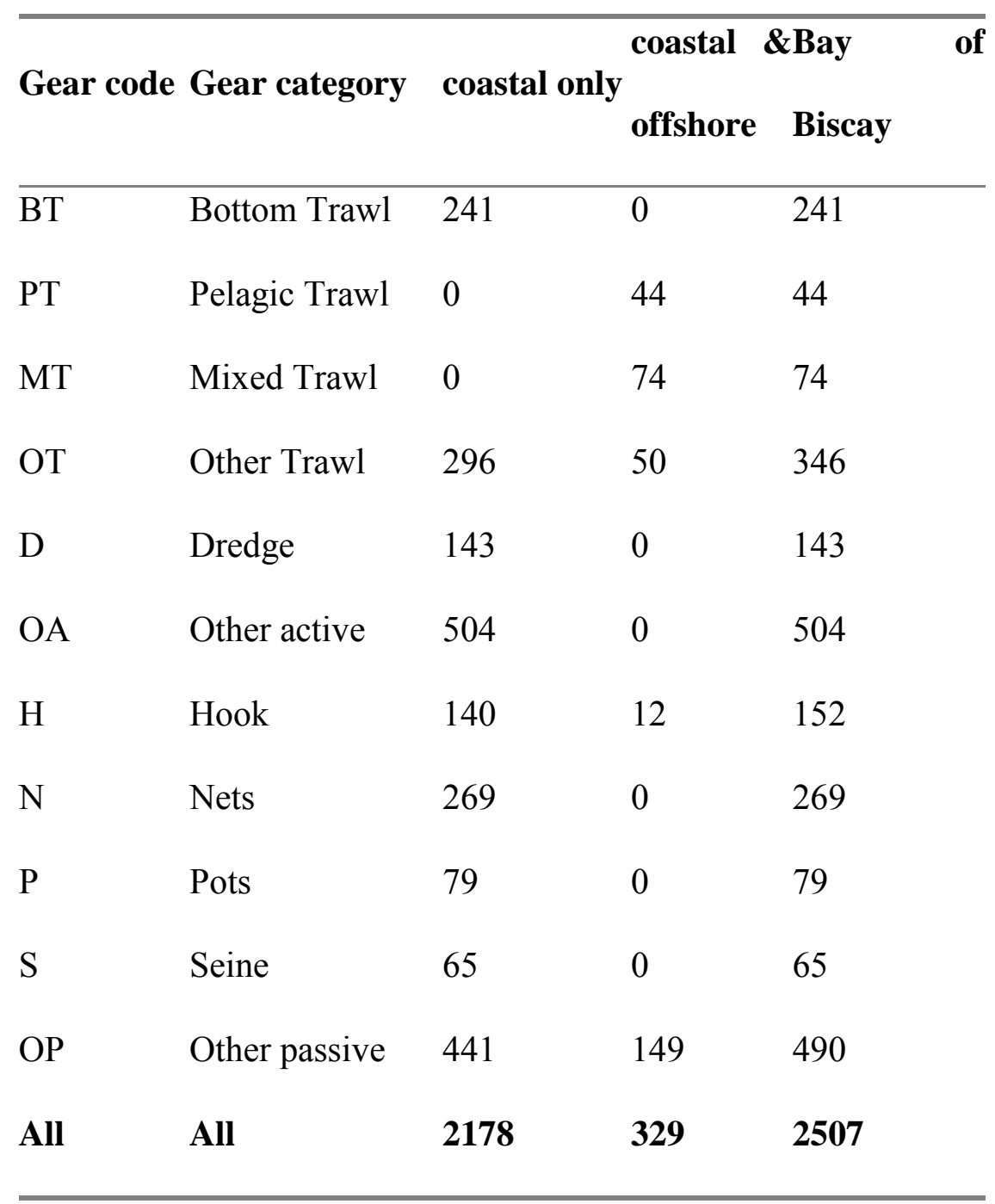


Table 2. Models for explaining annual cost components and gross added value fitted to a sample of French fishing vessels operating in the Bay of Biscay (2000-2009). Variables in final models selected by BIC are in bold. $\mathrm{s}()$ are smooth functions for continuous explanatory variables; s(var| gear) indicates separate smooth function by gear category.

\begin{tabular}{|c|c|c|c|c|}
\hline $\begin{array}{l}\text { Economic } \\
\text { variable }\end{array}$ & $\mathbf{n}$ & Explanatory variables & $\begin{array}{l}\text { BIC } \\
\text { final (full) } \\
\text { model }\end{array}$ & $\begin{array}{l}\text { \% Deviance } \\
\text { explained } \\
\text { by final } \\
\text { model }\end{array}$ \\
\hline fuel costs & 1975 & $\begin{array}{l}\text { year }+\mathrm{s}(\text { fuel price } \mathrm{x} \text { days-at-sea } \mid \text { gear })+ \\
\mathrm{s}(\text { power } \mid \text { gear })+\text { fishing zone }\end{array}$ & $\begin{array}{l}38280 \\
(38394)\end{array}$ & 82.7 \\
\hline landings costs & 2265 & $\begin{array}{l}\text { year }+ \text { district }+\mathrm{s}(\text { total revenue } \mid \text { gear, } \\
\text { district })+\mathrm{s}(\text { length } \mid \text { gear })\end{array}$ & $\begin{array}{l}42172 \\
(42290)\end{array}$ & 73.0 \\
\hline salary costs & 2245 & $\begin{array}{l}\text { year }+ \text { district }+\mathrm{s}(\text { total revenue } \mid \text { gear })+ \\
\mathrm{s}(\text { crew } \mid \text { gear })+\mathrm{s}(\text { days-at-sea })\end{array}$ & $\begin{array}{l}45872 \\
(45876)\end{array}$ & 97.8 \\
\hline $\begin{array}{l}\text { other variable } \\
\text { costs }\end{array}$ & 2476 & $\begin{array}{l}\text { year }+ \text { gear }+ \text { fishing zone }+\mathrm{s}(\text { days-at- } \\
\text { sea } \mid \text { gear })+\mathrm{s}(\text { length })+\mathrm{s}(\text { power })\end{array}$ & $\begin{array}{l}42959 \\
(43039)\end{array}$ & 60.9 \\
\hline total fixed costs & 2498 & $\begin{array}{l}\text { year }+ \text { district }+ \text { gear }+\mathrm{s}(\text { age } \mid \text { gear })+ \\
\mathrm{s}(\text { length } \mid \text { gear })\end{array}$ & $\begin{array}{l}52703 \\
(52797)\end{array}$ & 80.8 \\
\hline total costs & 2490 & $\begin{array}{l}\text { year }+ \text { fishing zone }+ \text { gear }+\mathrm{s}(\text { total } \\
\text { revenue })+\mathrm{s}(\text { age })+\mathrm{s}(\text { days-at-sea } \\
\text { gear })+\mathrm{s}(\text { length })\end{array}$ & $\begin{array}{l}53498 \\
(53504)\end{array}$ & 92.4 \\
\hline $\begin{array}{l}\text { gross added } \\
\text { value }\end{array}$ & 2484 & $\begin{array}{l}\text { year }+ \text { fishing zone }+ \text { gear }+\mathrm{s}(\text { length } \mid \\
\text { gear })+s(\text { days-at-sea } \mid \text { gear })+\mathrm{s}(\text { power } \mid \\
\text { gear })\end{array}$ & $\begin{array}{l}59098 \\
(59197)\end{array}$ & 65.8 \\
\hline
\end{tabular}

fuel price: mean annual fuel price per litre. 


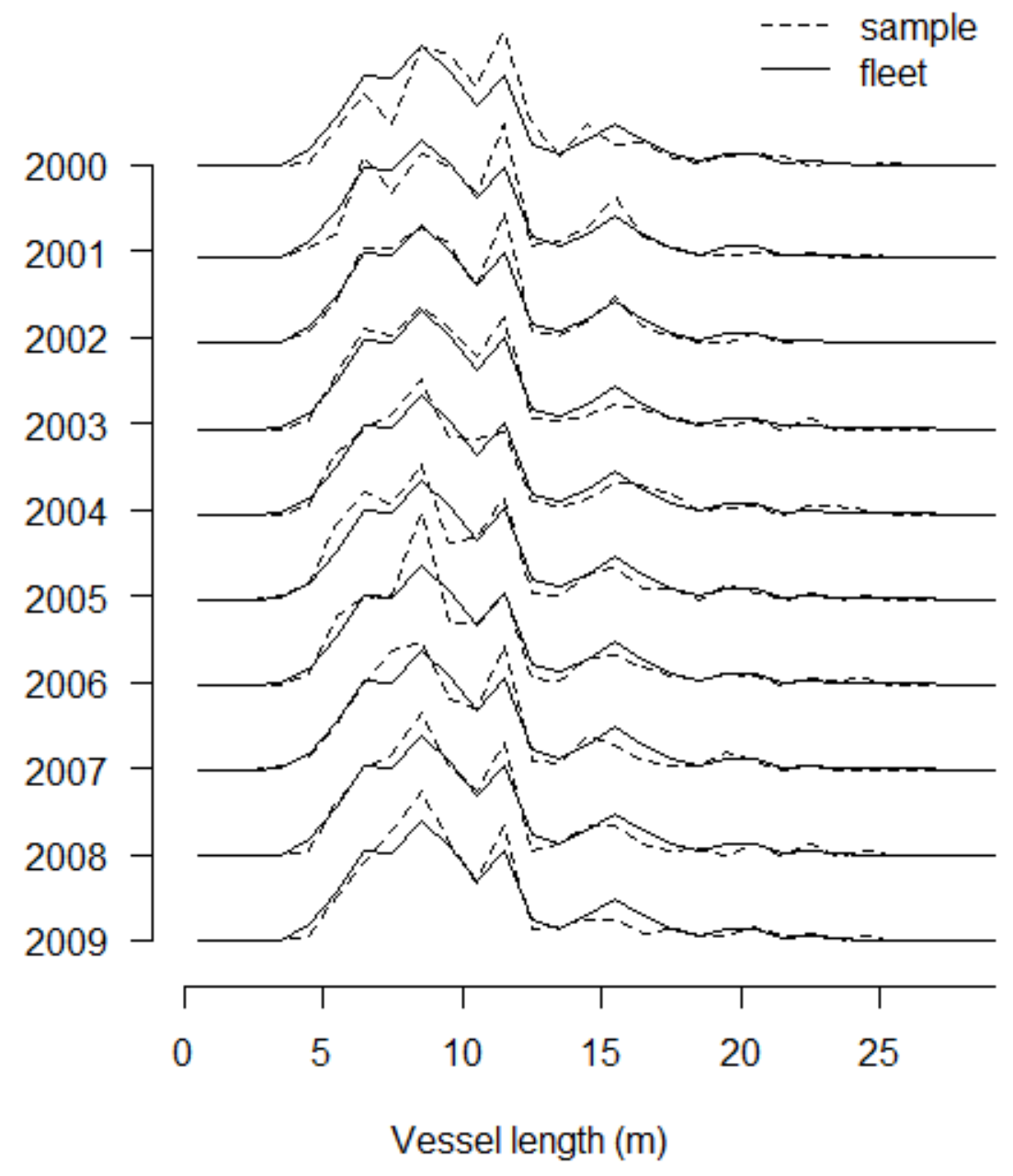

Figure 1. Vessel size in economic sample and population for French vessels operating in the Bay of Biscay 2000-2009. 


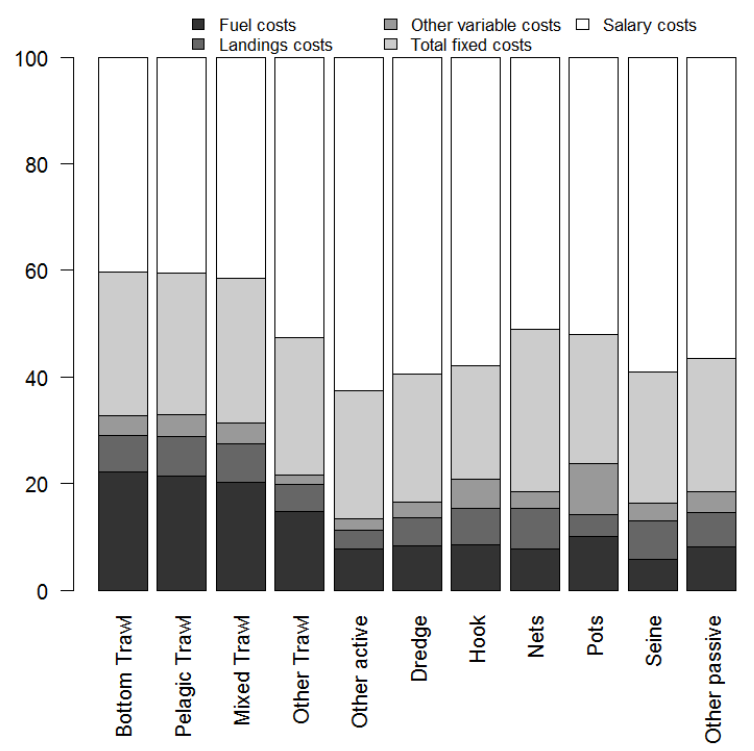

Figure 2. Composition of annual fishing costs by gear category for French vessels operating primarily in the Bay of Biscay (average for period 2000-2009). 

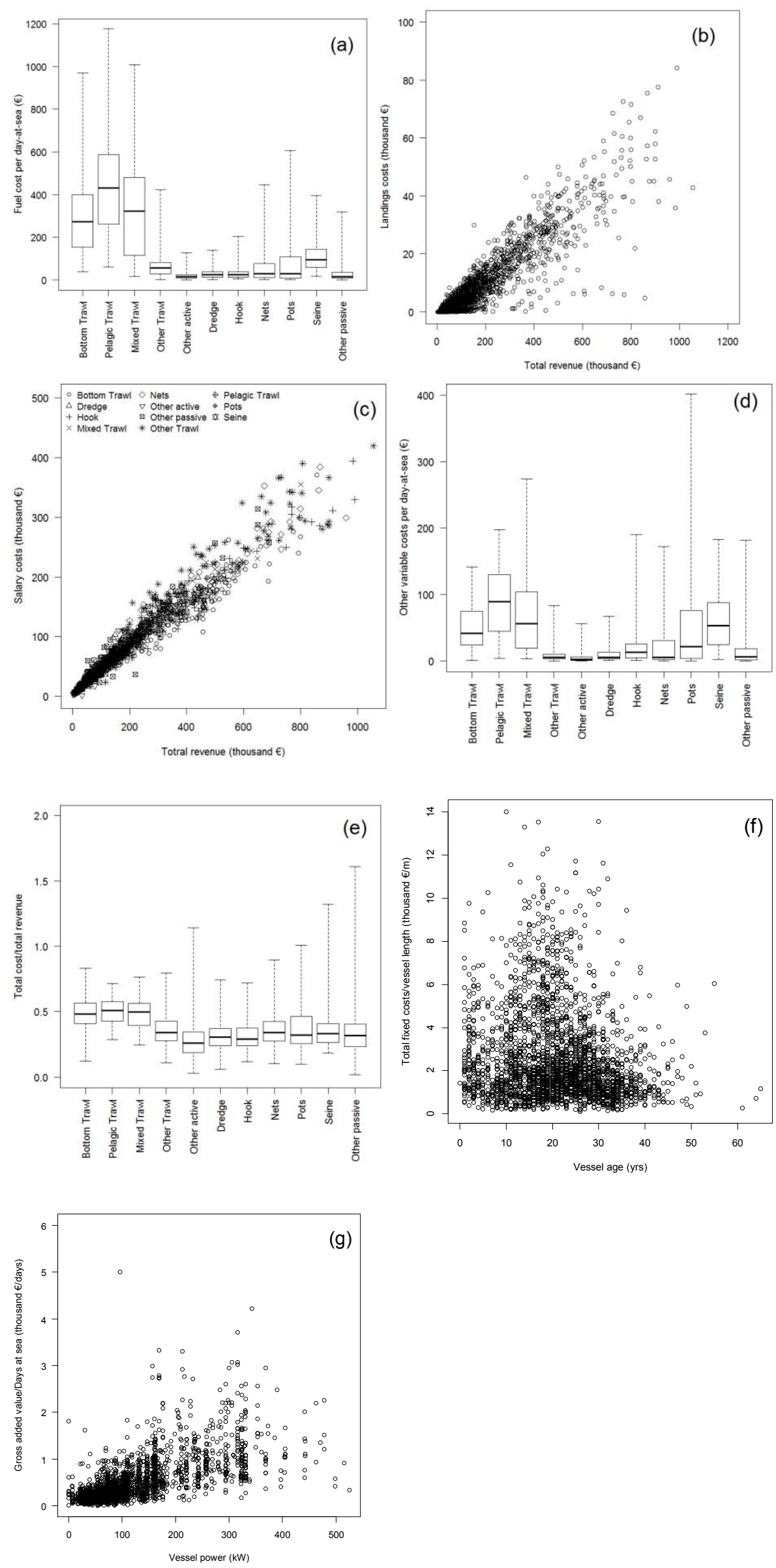
Figure 3. Annual economic variables for sample of French vessels operating in the Bay of Biscay 2000-2009. a) annual fuel costs per day-at-sea by gear category; b) annual landings costs as a function of total revenue and maritime vessel registration region; c) annual salary costs as a function of total revenue by gear category; d) other variable costs by gear category; e) ratio annual total costs (excluding salaries) to total revenue by gear category; (f) ratio total fixed costs to vessel power vs. vessel age; (g) ratio gross added value to days at sea vs. vessel power. In boxplots boxes span from 25 th to 75 th percentile and whiskers from minimum to maximum values; the median is indicated by a bold horizontal line. 


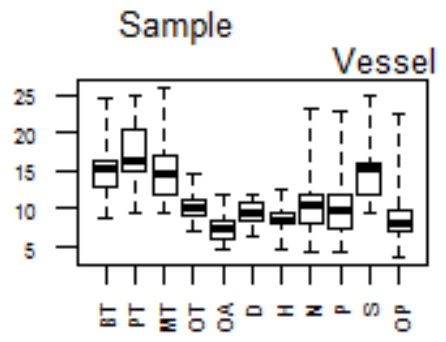

Fleet

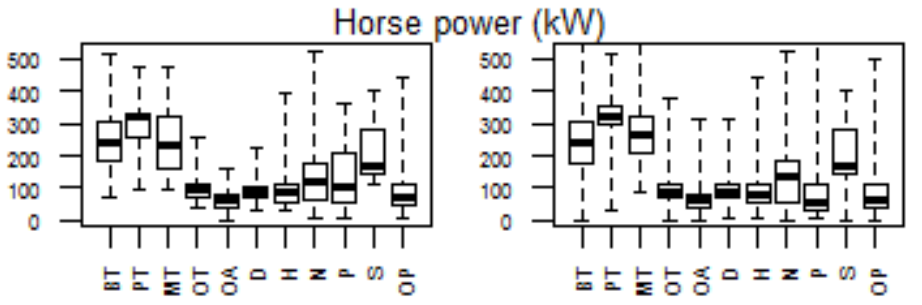

Vessel age (yrs)
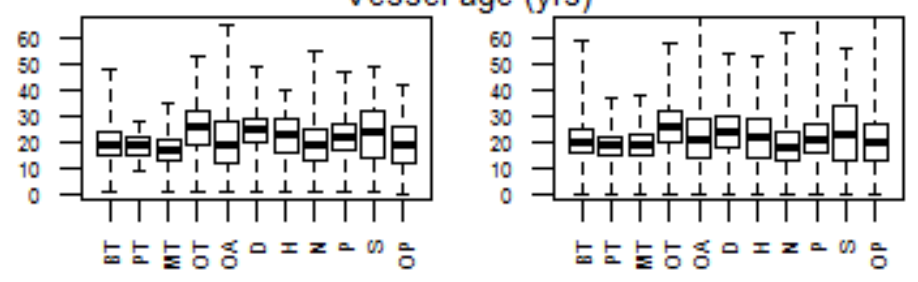

Crew size
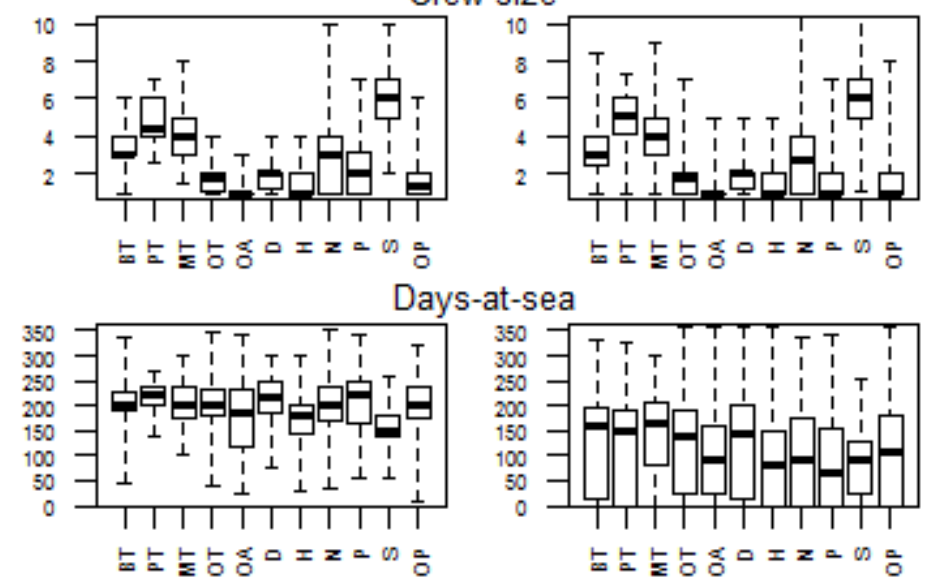

Total revenue (Mio $€$ )
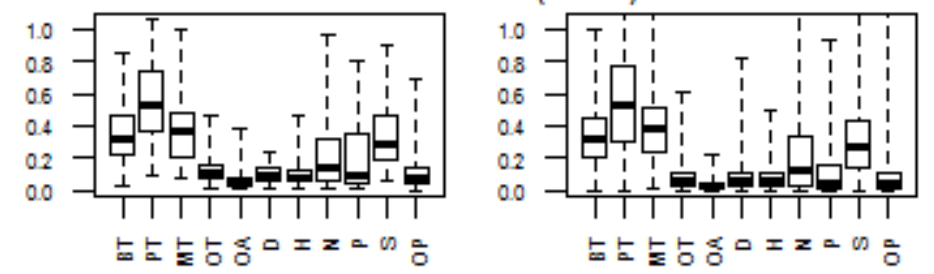

Gear category

Figure 4. Boxplots for explanatory variables for economic sample and all French vessels fishing in Bay of Biscay 2000-2009 by gear category (for abbreviations see table 1). Boxes span from 25 th to 75 th percentile and whiskers from minimum to maximum values the medium is indicated by a bold horizontal line. 

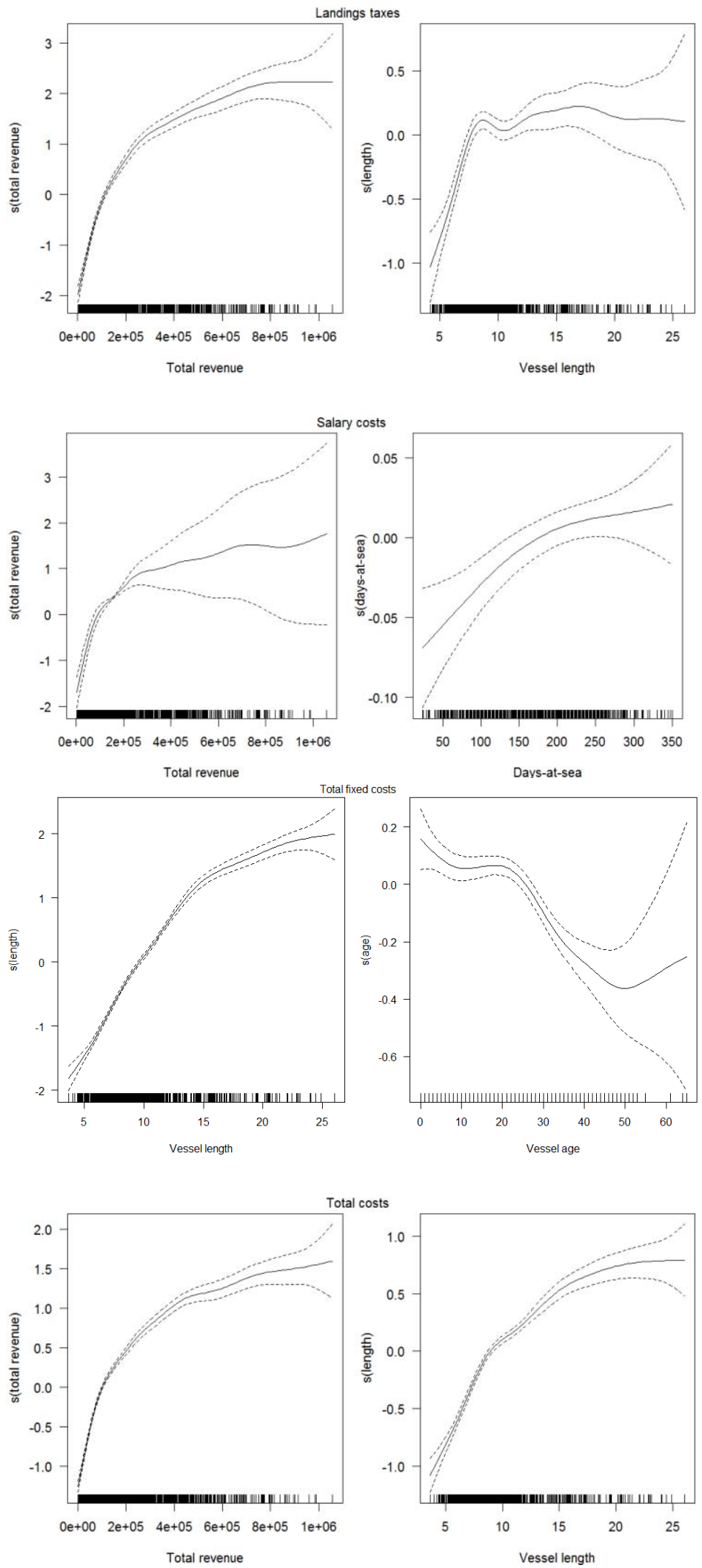

Figure 5. Fitted smooth explanatory functions for economic variables on scale of linear predictor (Gamma distribution with log-link). Bands are approximate $95 \%$ confidence bands. 

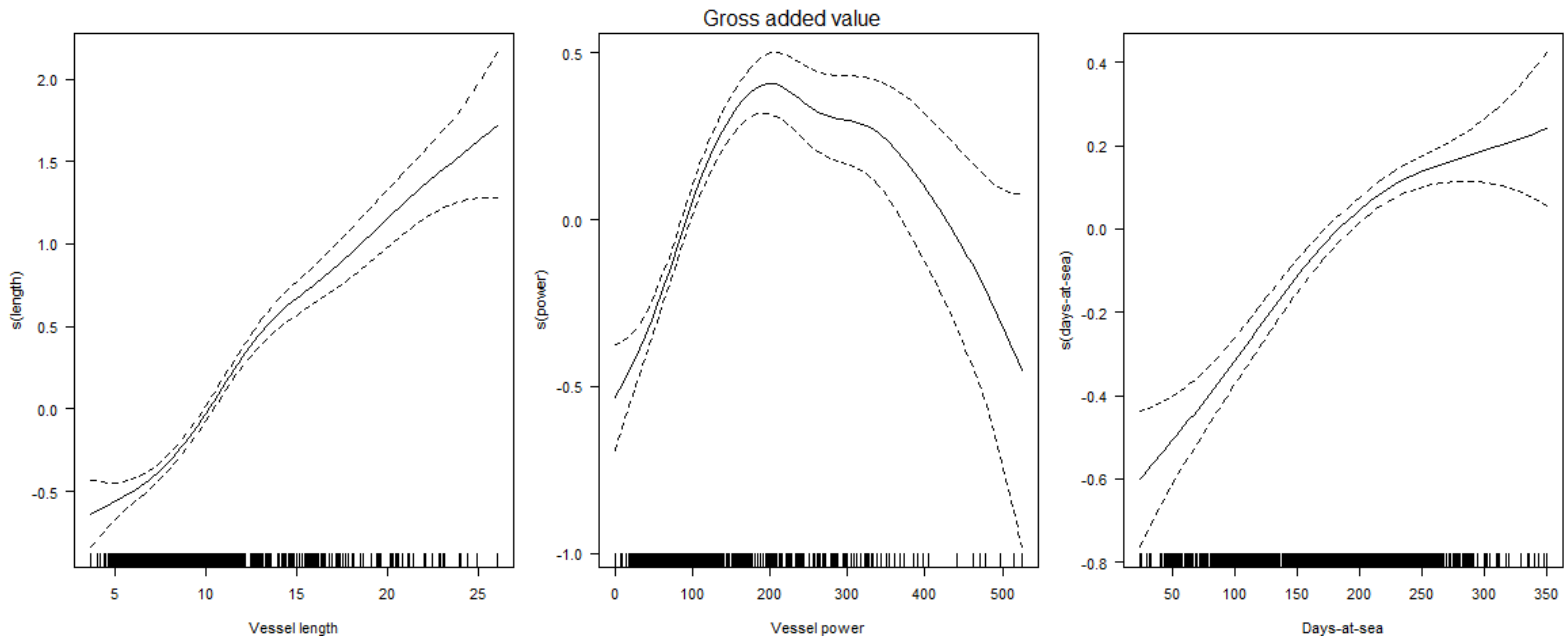

Figure 6. Fitted smooth explanatory functions for gross added value (total revenue - total costs) on scale of linear predictor (Gamma distribution with log-link). Bands are approximate $95 \%$ confidence bands. 


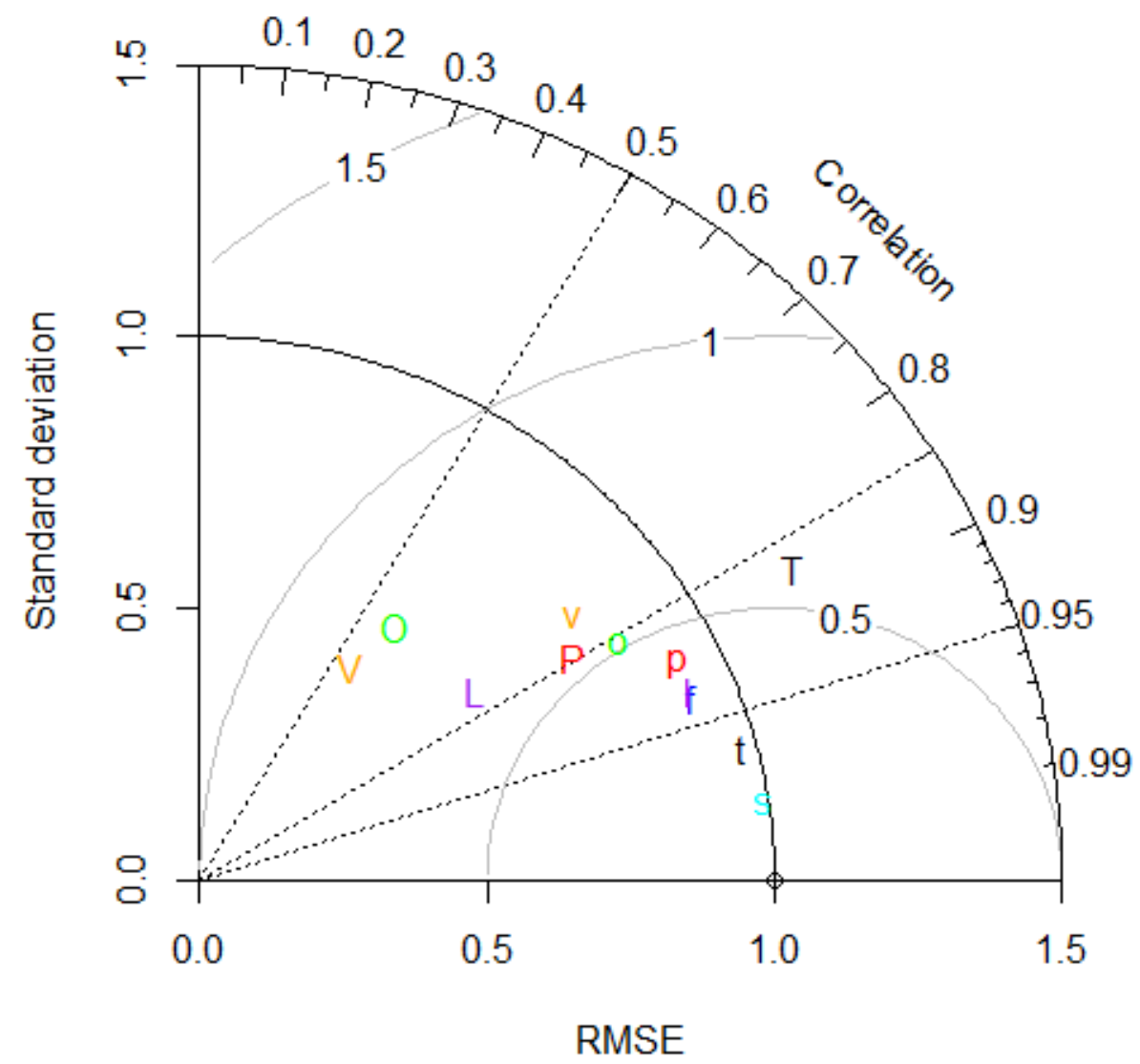

Figure 7. Taylor diagram for comparison between economic model predictions and observations using the ratio of standard deviations $\left(\sigma_{\text {pred }} / \sigma_{\text {obs }}\right)$, the root mean square error (RMSE) and the Spearman correlation. Values are standardised so that the observations in the Bay of Biscay (indicated by circle) have correlation 1 with themselves, standard deviation 1 and RMSE 0.

Lower case characters are for Bay of Biscay sample for which the economic models were fitted (Table 2). Upper case letters are for predictions in the English Channel using fitted model from the Bay of Biscay. Models: $\mathrm{t} / \mathrm{T}$ total costs, $\mathrm{v} / \mathrm{V}$ gross added value; s salary costs; 1/L landings costs; $\mathrm{o} / \mathrm{O}$ other variable costs; $\mathrm{p} / \mathrm{P}$ total fixed costs; $\mathrm{f}$ fuel costs. $\mathrm{S}$ and $\mathrm{F}$ values for English Channel are outside plot region. 

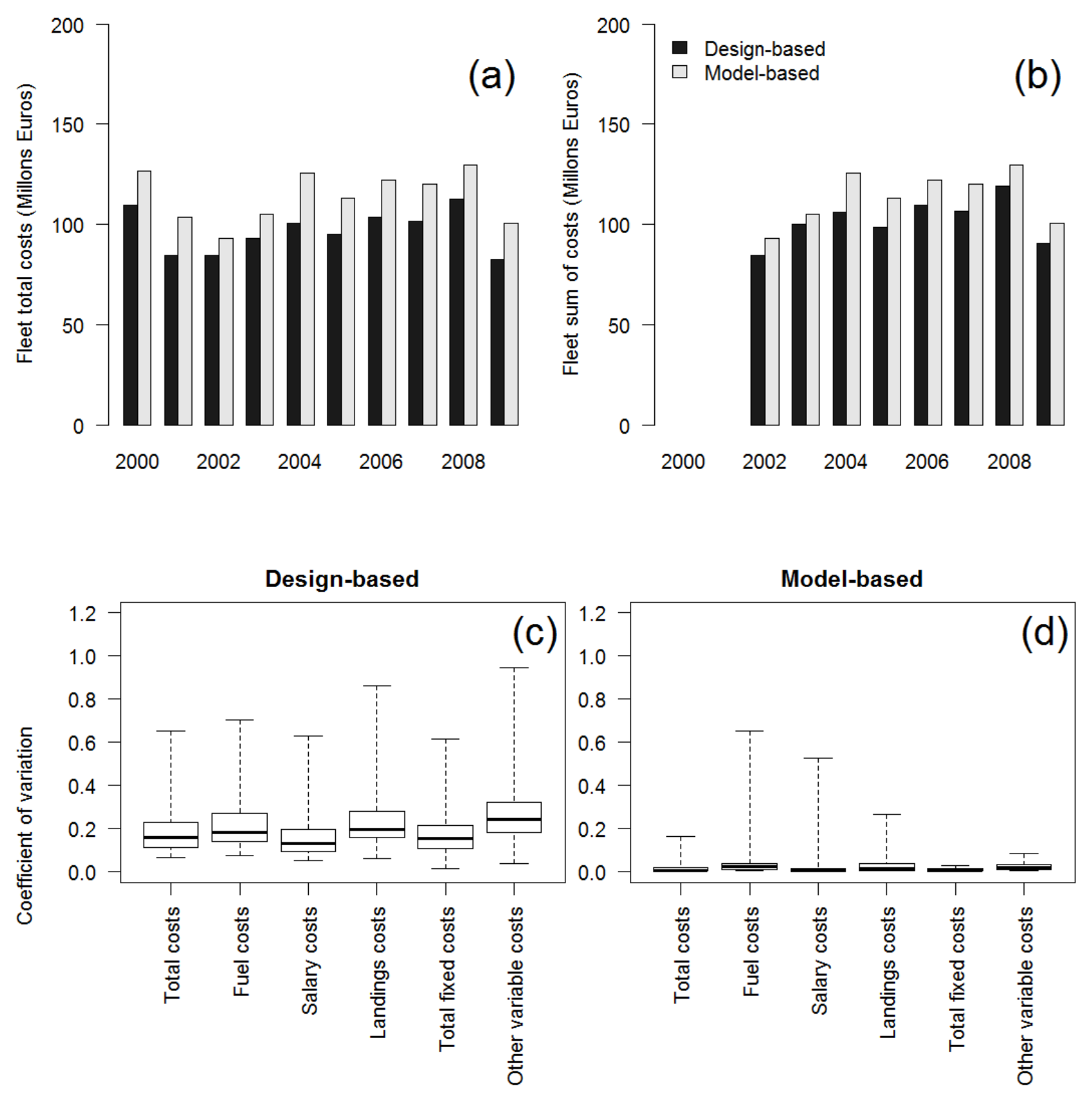

Figure 8. Comparison of design-based and model based cost estimates at the French fleet level in the Bay of Biscay. (a) Direct estimates of total costs (excluding salary), (b) Estimates obtained as sum of total variable and total fixed costs. c) CV of design-based fleet level cost estimates; d) CV of model-based cost estimates. 